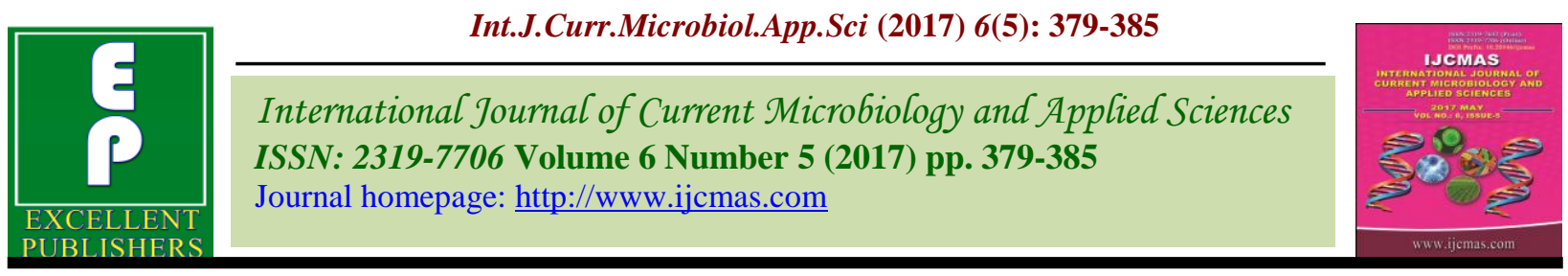

Original Research Article https://doi.org/10.20546/ijcmas.2017.605.043

\title{
Carrier Based Formulation of Plant Growth Promoting Bacillus Species and their Effect on Different Crop Plants
}

\author{
A. Pahari, A. Pradhan, S. Maity and B.B. Mishra* \\ Department of Microbiology, College of Basic Science and Humanities, \\ Orissa University of Agriculture and Technology, Bhubaneswar - 751 003, Odisha, India \\ *Corresponding author
}

\begin{tabular}{|c|c|}
\hline & A B S T R A C T \\
\hline $\begin{array}{l}\text { Ke y w or d s } \\
\text { Bacillus, } \\
\text { Formulation, } \\
\text { Plant growth, } \\
\text { Phytopathogen, } \\
\text { Charcoal. } \\
\end{array}$ & \multirow{3}{*}{$\begin{array}{l}\text { Rhizospheric microbes have immense potentiality to synthesize and release various } \\
\text { compounds, that are regulating plant growth as well as physical and chemical texture of } \\
\text { the soil. In this small piece of research, we evaluated the plant growth promoting activity } \\
\text { of two different carriers such as charcoal and talc based formulation of Bacillus species. It } \\
\text { was observed that, the bio-inoculants were able to enhance the organic carbon, nitrogen, } \\
\text { phosphorous and potassium in soil, there by promoting growth of test crop plants such as } \\
\text { mung bean (Vigna radiata L.) and rice (Oryza satiava L.). Charcoal based formulation } \\
\text { depicts higher plant growth promoting activity in comparison with other carrier. Moreover, } \\
\text { the Bacillus specie showed antagonistic effect against different phytopathogens including } \\
\text { Rahizoctonia solani (ITCC-186) and Fusarium oxysporum (ITCC-578). Thus, the charcoal } \\
\text { based formulation of Bacillus specie can be used for plant growth promoting activity of } \\
\text { various crops. Before field application extensive research is highly indispensable in this } \\
\text { regard. }\end{array}$} \\
\hline Article Info & \\
\hline $\begin{array}{l}\text { Accepted: } \\
\text { 04 April } 2017 \\
\text { Available Online: } \\
\text { 10 May } 2017\end{array}$ & \\
\hline
\end{tabular}

\section{Introduction}

With advent of civilization, population explosion has demanded more space for industrialization, urbanization resulting decrease in agricultural land. The present day problem is to produce food grain with the available land without affecting soil health has become a great challenge to scientists. Soil harbors a wide array of microbes, among them several beneficial bacteria are colonizing in the rhizospheric region their by promoting growth of plant. Such type bacteria are generally affiliated as PGPR (Plant Growth-Promoting Rhizobacteria). Plant growth promotion by the PGPR can be either through stimulating plant growth by the production of phytohormones or by the application of bio inoculants to control various plant diseases (Glick, 1995; Bashan and de-Bashan, 2005; Bloemberg and Lugtenberg, 2001; Sivakumar et al., 2014).

In the present scenario development of carrier based formulation of bio-inoculant is an industrial skill to renovate a promising laboratory documented bacteria to a commercial profitable field product (Bashan, 1998). Formulation characteristically should contain active constituent or ingredient in a suitable carrier with additives that will assist in the stabilization and perform as protective shield of the bacterial cells during storage, transportation and at the target region. It is 
easy to handle, increase the activity of the organism in the field, cost-effective and convenient for field applications. For this bioagent dependent technology, screening of microbes for desirable traits, selection of potential strains and inoculum development are important steps.

Bashan (1998) reviewed that, viability of inoculum in a suitable formulation for a definite duration is vital for the commercialization of the product. Importance of formulation is to obtain the desired benefit when applied to soil by maintaining the bacterial cell and the active constituent to be in a metabolically and physiologically competent state.

According to Cassidy et al., (1996), immobilization of bacterial cells into polymer matrix has confirmed to be beneficial over direct inoculation to the soil.

A major purpose of bacterial inoculant formulation is to offer more suitable microhabitat for survival in the soil ecosystem. Moreover, for field applications use of encapsulated cells has several advantages over free cell formulations namely, protection from biotic stresses (Smit et al., 1996) and abiotic stresses such as the inhibitory effect of toxic compounds (Cassidy et al., 1997), enhanced survival and improved physiological activity (Weir et al., 1995), supply of encapsulated nutritional additives (Trevors et al., 1993), increased cell densities and preferential cell growth in various internal aerobic and anaerobic zones of encapsulating gel. In view of this, the small piece of research is focused towards evaluation of biocontrol efficacy of the potential PGPR isolate against different phyto-pathogens and development of carrier based formulation of PGPR isolates and study their effect on growth of Mung bean and Rice plant by pot culture method.

\section{Materials and Methods}

\section{Inoculum preparation for green house study}

Previously isolated Bacillus species (Pradhan et al., 2015) was taken from the glycerol stock and streaked onto nutrient agar. Single colony of the bacteria was inoculated and grown in tryptone yeast extract broth with constant shaking at $150 \mathrm{rpm}$ for $48 \mathrm{~h}$ at room temperature. The culture obtained at stationary phase was centrifuged at $6000 \mathrm{rpm}$ for $10 \mathrm{~min}$ and bacterial cells re-suspended in phosphate buffer (100 mM, pH. 7.0). The cell concentration was adjusted to $9 \times 10^{8} \mathrm{cfu} / \mathrm{ml}$. $\left(0.3 \mathrm{OD}\right.$ at $\left.595 \mathrm{~nm}=10^{8} \mathrm{cfu} / \mathrm{ml}\right)$.

\section{Talc-based formulation of Bacillus species}

The talc-based formulation was prepared by following the method described by Vidhyasekaran and Muthamilan (1995). A loopful bacterial culture was inoculated into the tryptone yeast extract broth and incubated in a rotary shaker at $150 \mathrm{rpm}$ for $48 \mathrm{~h}$ at room temperature $\left(25 \pm 2^{0} \mathrm{C}\right)$. One $\mathrm{kg}$ of sterilized talc powder was taken in a metal tray and its $\mathrm{pH}$ was adjusted to neutral by adding $\mathrm{CaCO}_{3}$ at the rate of $15 \mathrm{~g} / \mathrm{kg} .10 \mathrm{gm}$ of $\mathrm{CMC}$ was added to $1 \mathrm{~kg}$ of talc powder and mixed well. This mixture was autoclaved for $30 \mathrm{~min}$ on each of two consecutive days. The $400 \mathrm{ml}$ of $48 \mathrm{~h}$ grown bacterial suspension containing 9 $\times 10^{8} \mathrm{cfu} / \mathrm{ml}$ was mixed with carrier-CMC mixture under aseptic conditions. After drying overnight in laminar air flow hood, it was packed in polypropylene bag, sealed and stored at room temperature $\left(25 \pm 2{ }^{0} \mathrm{C}\right)$.

\section{Charcoal-based formulation of Bacillus species}

Charcoal-based formulation was developed as described by Trivedi et al., 2005. The bacterial culture was grown in on tryptone 
yeast extract (TYE) broth at $28 \pm 2^{\circ} \mathrm{C}$ for $24-$ $48 \mathrm{~h}$ rising the final concentration of $9 \times 10^{9} \mathrm{cfu} / \mathrm{ml} .150 \mathrm{gm}$ of sterile charcoal was mixed with $150 \mathrm{ml}$ bacterial suspension and 10 gm of gur (local sugar) was added. The slurry was mixed properly under aseptic conditions and air dried at $28 \pm 2^{\circ} \mathrm{C}$ overnight in a laminar flow hood.

\section{Greenhouse study}

The seeds of Mung bean (OUM-11-5) and Rice (Lalat) were obtained from the Department of Agronomy, OUAT and these seeds were soaked overnight in water, surface sterilized with $0.2 \% \mathrm{HgCl}_{2}$ solution for $2-3$ min and air dried for $15 \mathrm{~min}$. The seeds were soaked in double volume of sterile distilled water containing different formulation (10 $\mathrm{gm} / \mathrm{L}$ ) (Salaheddin et al., 2010) and the treated seeds were shade dried for $30 \mathrm{~min}$. Total $4 \mathrm{~kg}$ of sterilized soil was taken in each pot and the holes of the pots were closed to prevent of drainage of water. The bacteria treated seeds were showed in soil (diameter $0.25 \mathrm{~m}$; height $0.3 \mathrm{~m}$ ) at the rate of 7 seeds per pot and un-inoculated seeds were served as control. After 45 days the total chlorophyll content in leaf was measured by using the method stated by Arnon (1949) and growth parameters such as root length, shoot length and Biomass were recorded after harvesting. Physico-chemical parameters such as organic carbon, $\mathrm{pH}$, Electrical conductivity (ds/m), available $\mathrm{N}(\mathrm{kg} / \mathrm{ha}), \mathrm{P}_{2} \mathrm{O}_{5}$ and $\mathrm{K}_{2} \mathrm{O}(\mathrm{kg} / \mathrm{ha})$ of the soil and total bacterial population in each pot were also studied in regular interval.

\section{Testing of in vitro antagonism}

The antagonistic effect of Bacillus sp. was tested for by duel culture method against two common plant pathogen Rahizoctonia solani (ITCC-186) and Fusarium oxysporum (ITCC578). Spores of fungal cultures grown on patato dextrose agar medium (PDA). A $5 \mathrm{~mm}$ diameter mycelial agar disc was cut from the margin of 7-day-old fungus culture and placed on one side of a $9 \mathrm{~cm}$ Petri dish containing PDA medium and test bacteria was streaked on the other end of the Petri dish. Plates were incubated at $28^{0} \mathrm{C} \pm 2{ }^{\circ} \mathrm{C}$ for 5 to 8 days. Dishes inoculated only with test pathogens served as controls. The percent of inhibition of each fungus was measured using the formula (Vincent, 1927): Inhibition percentage $(\%)=(\mathrm{R} 1-\mathrm{R} 2) / \mathrm{R} 1 \mathrm{X} 100$ where $\mathrm{R} 1$ is radial growth of mycelia in control and $\mathrm{R} 2$ is radial growth of mycelia in treatment.

\section{Statistical analysis}

All the experiment was done in triplicate and the data was analyzed statistically by one way ANOVA at $p<0.05$ significant level.

\section{Results and Discussion}

Carrier based formulation protect the bacteria against many environmental stress; release to the soil, slowly but in large quantities. In the present study it was found that, talc based and charcoal based formulations of Bacillus species effectively increase the growth of Mung bean and rice when it was applied as seed treatment. Increased root and shoot elongation was apparent in PGPR treated seeds compared to control. Several strains of $B$. subtilis have proven to be efficient in plant growth promotion (Bai et al., 2003). In case mung bean and rice, the highest root elongation, shoot elongation and increase in total biomass in respect to the control observed when the seeds were treated with different carrier based formulation (Tables 1 and 2). Highest root $(22.83 \mathrm{~cm})$ and shoot elongation $(43.53 \mathrm{~cm})$ was recorded in case of mung bean and $22.67 \mathrm{~cm}$ root length and $75.97 \mathrm{~cm}$ shoot length was observed in case of rice when seeds were pre-treated with Charcol-based formulation. The total chlorophyll content of rice and mung bean of different treatment were also recorded (Table $5)$. 
Table.1 Effect of different bacterial formulation on shoot length, root length and Biomass of mung bean

\begin{tabular}{|c|l|c|c|}
\hline Sample & Root length(cm) & Shoot length(cm) & Biomass $($ gm) \\
\hline Control & $17.37 \pm 0.56$ & $35.73 \pm 0.45$ & $22.17 \pm 0.47$ \\
\hline Charcoal based formulation & $22.83 \pm 0.52$ & $43.53 \pm 0.67$ & $31.58 \pm 0.89$ \\
\hline Talc based formulation & $20.66 \pm 0.47$ & $42.04 \pm 0.14$ & $26.62 \pm 0.75$ \\
\hline
\end{tabular}

Values represents mean \pm SE and highly significant at $p<0.05$

Table.2 Effect of different bacterial formulation on shoot length, root length and biomass of rice plant

\begin{tabular}{|c|c|c|c|}
\hline Sample & Root length(cm) & Shoot length(cm) & Biomass (gm) \\
\hline Control & $15.36 \pm 0.3$ & $37.06 \pm 0.5$ & $19.88 \pm 0.31$ \\
\hline Charcoal based formulation & $22.67 \pm 0.52$ & $75.97 \pm 0.44$ & $25.90 \pm 0.34$ \\
\hline Talc formulation & $20.97 \pm 0.84$ & $71.11 \pm 0.31$ & $21.66 \pm 0.35$ \\
\hline
\end{tabular}

Values represents mean \pm SE and highly significant at $\mathrm{p}<0.05$

Table.3 Effect of formulated bacteria on soil physico-chemical parameter of Mung bean

\begin{tabular}{|l|l|l|l|l|l|l|l|l|l|l|l|l|}
\hline \multirow{2}{*}{$\begin{array}{l}\text { Soil } \\
\text { parameter }\end{array}$} & \multicolumn{2}{|c|}{$\mathbf{p H}$} & \multicolumn{2}{c|}{$\mathbf{E . C}(\mathbf{d} / \mathbf{m})$} & \multicolumn{2}{c|}{$\mathbf{O . C}(\boldsymbol{\%})$} & \multicolumn{2}{c|}{$\mathbf{N}(\mathbf{k g} / \mathbf{h a})$} & \multicolumn{2}{|c|}{$\mathbf{P}_{\mathbf{2}} \mathbf{O}_{\mathbf{5}}(\mathbf{k g} / \mathbf{h a})$} & \multicolumn{2}{|c|}{$\mathbf{K}_{\mathbf{2}} \mathbf{O}(\mathbf{k g} / \mathbf{h a})$} \\
\cline { 2 - 13 } & $\mathrm{BS}$ & $\mathrm{AH}$ & $\mathrm{BS}$ & $\mathrm{AH}$ & $\mathrm{BS}$ & $\mathrm{AH}$ & $\mathrm{BS}$ & $\mathrm{AH}$ & $\mathrm{BS}$ & $\mathrm{AH}$ & $\mathrm{BS}$ & $\mathrm{AH}$ \\
\hline Control & 6.81 & 6.81 & 0.011 & 0.011 & 0.211 & 0.223 & 155.5 & 158.75 & 83.9 & 84.26 & 197.4 & 198.8 \\
& \pm & \pm & \pm & \pm & \pm & \pm & \pm & \pm & \pm & \pm & \pm & \pm \\
& 0.01 & 0.01 & 0.01 & 0.01 & 0.01 & 0.01 & 0.32 & 0.74 & 0.31 & 0.45 & 0.42 & 0.25 \\
\hline Charcoal & 6.81 & 6.85 & 0.011 & 0.014 & 0.211 & 0.529 & 155.5 & 277.2 & 83.9 & 87.97 & 197.4 & 199.61 \\
formulation & \pm & \pm & \pm & \pm & \pm & \pm & \pm & \pm & \pm & \pm & \pm & \pm \\
& 0.01 & 0.01 & 0.01 & 0.01 & 0.01 & 0.01 & 0.32 & 0.66 & 0.31 & 1.4 & 0.42 & 0.38 \\
\hline Talc & 6.81 & 6.82 & 0.012 & 0.011 & 0.211 & 0.423 & 155.5 & 251.58 & 83.9 & 85.17 & 197.4 & 199.03 \\
formulation & \pm & \pm & \pm & \pm & \pm & \pm & \pm & \pm & \pm & \pm & \pm & \pm \\
& 0.01 & 0.01 & 0.01 & 0.01 & 0.01 & 0.01 & 0.32 & 1.45 & 0.31 & 0.35 & 0.42 & 0.34 \\
\hline
\end{tabular}

Values represents mean \pm SE and highly significant at $\mathrm{p}<0.05$

Table.4 Effect of formulated bacteria on soil physico-chemical parameter of rice

\begin{tabular}{|l|l|l|l|l|l|l|l|l|l|l|l|l|}
\hline \multirow{2}{*}{$\begin{array}{l}\text { Soil } \\
\text { parameter }\end{array}$} & \multicolumn{2}{|c|}{$\mathbf{p H}$} & \multicolumn{2}{c|}{$\mathbf{E . C}(\mathbf{d s} / \mathbf{m})$} & \multicolumn{2}{c|}{$\mathbf{O . C}(\mathbf{\%})$} & \multicolumn{2}{c|}{$\mathbf{N}(\mathbf{k g} / \mathbf{h a})$} & \multicolumn{2}{c|}{$\mathbf{P}_{2} \mathbf{O}_{\mathbf{5}}(\mathbf{k g} / \mathbf{h a})$} & \multicolumn{2}{|c|}{$\mathbf{K}_{\mathbf{2}} \mathbf{O}(\mathbf{k g} / \mathbf{h a})$} \\
\cline { 2 - 13 } & BS & AH & BS & AH & BS & AH & BS & AH & BS & AH & BS & AH \\
\hline Control & 6.81 & 6.81 & 0.011 & 0.011 & 0.211 & 0.218 & 155.5 & 156.64 & 83.9 & 89.55 & 197.4 & 197.71 \\
& \pm & \pm & \pm & \pm & \pm & \pm & \pm & \pm & \pm & \pm & \pm & \pm \\
& 0.01 & 0.01 & 0.01 & 0.01 & 0.01 & 0.01 & 0.32 & 1.86 & 0.31 & 0.32 & 0.42 & 0.20 \\
\hline Charcoal & 6.81 & 6.85 & 0.011 & 0.014 & 0.211 & 0.538 & 155.5 & 274.76 & 83.9 & 89.37 & 197.4 & 199.77 \\
formulation & \pm & \pm & \pm & \pm & \pm & \pm & \pm & \pm & \pm & \pm & \pm & \pm \\
& 0.01 & 0.01 & 0.01 & 0.01 & 0.01 & 0.01 & 0.32 & 0.35 & 0.31 & 1.15 & 0.42 & 1.07 \\
\hline Talc & 6.81 & 6.82 & 0.012 & 0.011 & 0.211 & 0.422 & 155.5 & 243.69 & 83.9 & 85.56 & 197.4 & 197.69 \\
formulation & \pm & \pm & \pm & \pm & \pm & \pm & \pm & \pm & \pm & \pm & \pm & \pm \\
& 0.01 & 0.01 & 0.01 & 0.01 & 0.01 & 0.01 & 0.32 & 1.81 & 0.31 & 0.35 & 0.42 & 0.23 \\
\hline
\end{tabular}

Values represents mean $\pm \mathrm{SE}$ and highly significant at $\mathrm{p}<0.05$; BS= Before Sowing $\mathrm{Ah}=\mathrm{After}$ harvest 
Table.5 Estimation of total chlorophyll content in Rice and Mung bean plant

\begin{tabular}{|l|c|c|c|}
\hline \multicolumn{1}{|c|}{ Sample } & Control (mg/g) & Talc formulation $(\mathbf{m g} / \mathbf{g})$ & Charcoal formulation (mg/g) \\
\hline Mung bean & $3.37 \pm 0.04$ & $4.65 \pm 0.04$ & $4.76 \pm 0.11$ \\
\hline Rice & $1.65 \pm 0.23$ & $3.63 \pm 0.10$ & $4.18 \pm 0.30$ \\
\hline
\end{tabular}

Values represents mean \pm SE and highly significant at $\mathrm{p}<0.05$

Table.6 Total bacterial populationof Mung bean soil in different time interval

\begin{tabular}{|l|l|l|l|l|l|}
\hline \multicolumn{1}{|c|}{ Soil Parameter } & \multicolumn{1}{|c|}{ Initial day } & $\begin{array}{c}\text { 30 Days } \\
(\mathbf{C F U} / \mathbf{g m})\end{array}$ & $\begin{array}{c}\text { 60 Days } \\
(\text { CFU/gm })\end{array}$ & $\begin{array}{c}\text { 90 Days } \\
(\mathbf{C F U} / \mathbf{g m})\end{array}$ & $\begin{array}{c}\text { 120 Days } \\
(\mathbf{C F U} / \mathbf{g m})\end{array}$ \\
\hline Control & $3.4 \pm 0.02 \times 10^{5}$ & $3.47 \pm 0.14 \times 10^{5}$ & $3.47 \pm 0.20 \times 10^{5}$ & $3.53 \pm 0.24 \times 10^{5}$ & $3.63 \pm 0.24 \times 10^{5}$ \\
\hline Charcoal formulation & $3.4 \pm 0.02 \times 10^{5}$ & $5.87 \pm 0.12 \times 10^{5}$ & $6.23 \pm 0.24 \times 10^{5}$ & $6.47 \pm 0.2 \times 10^{5}$ & $6.63 \pm 0.29 \times 10^{5}$ \\
\hline Talc formulation & $3.4 \pm 0.02 \times 10^{5}$ & $5.43 \pm 0.20 \times 10^{5}$ & $5.9 \pm 0.13 \times 10^{5}$ & $6.1 \pm 0.2 \times 10^{5}$ & $6.37 \pm 0.18 \times 10^{5}$ \\
\hline
\end{tabular}

Values represents mean \pm SE and highly significant at $\mathrm{p}<0.05$

Table.7 Total bacterial population of rice soil in different time interval

\begin{tabular}{|l|l|l|l|l|l|}
\hline Soil parameter & Initial & $\begin{array}{l}\text { 15 days } \\
\text { (CFU/gm) }\end{array}$ & $\begin{array}{l}\text { 30 days } \\
\text { (CFU/gm) }\end{array}$ & $\begin{array}{l}\text { 45 days } \\
\text { (CFU/gm) }\end{array}$ & $\begin{array}{l}\text { 60 days } \\
\text { (CFU/gm) }\end{array}$ \\
\hline Control & $3.4 \pm 0.02 \times 10^{5}$ & $3.42 \pm 0.03 \times 10^{5}$ & $3.43 \pm 0.03 \times 10^{5}$ & $3.43 \pm 0.04 \times 10^{5}$ & $3.58 \pm 0.15 \times 10^{5}$ \\
\hline Charcoal formulation & $3.4 \pm 0.02 \times 10^{5}$ & $4.0 \pm 0.11 \times 10^{5}$ & $4.3 \pm 0.12 \times 10^{5}$ & $4.44 \pm 0.18 \times 10^{5}$ & $4.6 \pm 0.11 \times 10^{5}$ \\
\hline Talc formulation & $3.4 \pm 0.02 \times 10^{5}$ & $3.75 \pm 0.17 \times 10^{5}$ & $4.13 \pm 0.08 \times 10^{5}$ & $4.23 \pm 0.12 \times 10^{5}$ & $4.37 \pm 0.14 \times 10^{5}$ \\
\hline
\end{tabular}

Values represents mean \pm SE and highly significant at $\mathrm{p}<0.05$

Table.8 In vitro antagonistic effect of Bacillus sp. on mycellial growth of different plant pathogens

\begin{tabular}{|c|c|c|}
\hline \multirow{2}{*}{ Isolate No. } & \multicolumn{2}{|c|}{ Inhibition \% } \\
\cline { 2 - 3 } & Rhizoctonia solani & Fusarium oxysporum \\
\hline Bacillus species & $61.49 \pm 0.69$ & $59.33 \pm 0.48$ \\
\hline
\end{tabular}

Values represents mean \pm SE and highly significant at $\mathrm{p}<0.05$

It was also found that, the bio-inoculants were able to increase the organic carbon, nitrogen, phosphorous and potassium in soil, there by promoting growth of mung bean and rice (Tables 3 and 4) in respect to control. It was well established fact thatthe microbial members of soil communities are the most sensitive and rapid indicators for soil quality evaluation (Zelles, 1999; Zornoza et al., 2009). The $\mathrm{pH}$ of soil is one of the most important physicochemical parameter, which influence the mineral nutrient of soil quality and microorganism activity (Saseeswari et al.,
2015). In the present investigation it was observed that the bacterial population in all the treatments was increased in respect to the control (Tables 6 and 7). The potential Bacillus species was tested for in vitro antagonism against Rahizoctonia solani and Fusarium oxysporum and showed positive result (Table 8 ). It was already proved that plant growth promoting rhizobacteria can protect the plant from different types of plat pathogens (Raupach and Kloepper, 1998). Result of the current study showed the positive impacts of Bacillus specie. on growth 
of mung bean and rice plant compared to the compared to control. So as a simple and safe method, bacterization of seeds could be a promising technique for improvement of plant growth efficiency. Thus, the potential bacteria Bacillus sp. further investigated to increase productivity under field condition and use of PGPR as inoculants bio fertilizers is a novel approach to replace chemical fertilizers and pesticides for sustainable agriculture in India.

\section{Acknowledgement}

The authors are thankful to Dr. D.P. Samantaray, Assistant Professor, Department of Microbiology, OUAT and Staff of the Department of Vegetable science, OUAT for providing laboratory facilities during the period of study. The authors have no conflict of interest to declare.

\section{References}

Arnon, D.I. 1949. Copper enzymes in isolated chloroplasts, polyphenoxidase in Beta vulgaris. Plant Physiol., 24: 1-15.

Bai, Y., Zhou, X. and Smith, D.L. 2003. Enhanced soybean plant growth resulting from co-inoculation of Bacillus strains with Bradyrhizobiumjaponicum. Crop Sci., 43: 1774 -1781.

Bashan, Y. 1998. Inoculants of plant growthpromoting bacteria for use in agriculture. Biotechnol. Adv., 16: 729770.

Bashan, Y., and de-Bashan, L.E. 2005. Bacteria/plant growth-promotion. In: Hillel D, editor. Encyclopedia of soils in the environment. Oxford, UK: Elsevier. Vol. 1, pp. 103- 115.

Bloemberg, G.V., and Lugtenberg, B.J.J. 2001. Molecular basis of plant growth promotion and biocontrol by rhizobacteria. Curr. Opin. Plant Biol., 4: 343350 .
Cassidy, M.B., Lee, H. and Trevors, J.T. 1996. Environmental applications of immobilized microbial cells: A review. J. Ind. Microbiol., 16:17- 101.

Cassidy, M.B., Lee, H. and Trevors, J.T. 1997. Survival and activity of lac-lux marked Pseudomonas aeruginosa UG2Lr cells in encapsulated kcarageenan over 4 years at 48C. J. Microbiol. Meth., 30: 167 -170.

Glick, B.R. 1995. The enhancement of plant growth by free living bacteria. Canad. J. Microbiol., 41: 109-117.

Pradhan, A., and Mishra, B.B. 2015. Effect of plant growth promoting rhizobacteria on germination and growth of rice (Oryza Sativa L.). The Ecoscan, 9(1\&2): 213216.

Raupach, G.S. and Kloepper, J.W. 1998. Mixtures of plant growth promoting rhizobacteria enhance biological control of multiple cucumber pathogens. Phytopathol., 88: 1158-1164.

Salaheddin, K., Valluvaparidasan, V., Ladhalakshmi, D. and Velazhahan, R. 2010. Management of bacterial blight of cotton using a mixture of Pseudomonas fluorescens and Bacillus subtilis. Plant Protect. Sci., 46: 41-50.

Saseeswari, A., Kanimozhi, G. and Panneerselvam, A. 2015. Studies on physicochemical parameter and bacterial populations in sediment soil at Karankadu Mangrove forest, Ramanathapuram (Dt), Tamilnadu. Int. J. Sci., 4: 886 - 895 .

Sivakumar, P.K., Parthasarthi, R. and Lakshmipriya, $\quad$ V.P. 2014. Encapsulation of plant growth promoting inoculant in bacterial alginate beads enriched with humic acid. Int. J. Curr. Microbiol. App. Sci., 3: 415-422.

Smit, E., Wolters, A.C., Lee, H., Trevors, J.T. and van Elsas, J.D. 1996. Interaction between a genetically marked 
Pseudomonas fluorescence strain and bacteriophage $\varnothing \mathrm{R} 2 \mathrm{f}$ in soil: Effects of nutrients, alginate encapsulation, and the wheat rhizosphere. Microb. Ecol., 31: $125-140$.

Trevors, J.T., van Elsas, J.D., Lee, H. and Wolters, A.C. 1993. Survival of alginate encapsulated Pseudomonas fluorescence cells in soil. Appl. Microbiol. Biotechnol., 39: 637- 643.

Trivedi, P., Pandey, A. and Palni, S. 2005. Carrier-based preparations of plant growth-promoting bacterial inoculants suitable for use in cooler regions. Worl. J. Microbiol. Biotechnol., 21: 941-945.

Vidhyasekaran, P., and Muthamilan, M. 1995. Development of a formulation of Pseudomonas fluorescens for control of chickpea wilt. Plant Dis., 79: 782-786.

Vincent, J.M. 1927. Distortionn of fungal hyphae in presence of certation inhibitors. Nature, 59: 850.
Weir, S.C., Dupuis, S.P., Providenti, M.A., Lee, H. and Trevors, J.T. 1995. Nutrient enhanced survival of and phenanthrene mineralization by alginate encapsulated and free Pseudomonas sp. UG14Lr cells in creosote contaminated soil slurries. Appl. Microbiol. Biotechnol., 43: 946951.

Zelles, L. 1999. Fatty acid patterns of phospholipids and lipopolysaccharides in the characterization of microbial communities in soil: a review. Biol. Fertil. Soils, 29:111-129.

Zornoza, R., Guerrero, C., Mataix-Solera, J., Scow, K.M., Arcenegui, V. and MataixBeneyto, J. 2009. Changes in soil microbial community structure following the abandonment of agricultural terraces in mountainous areas of Eastern Spain. Appl. Soil Ecol., 42: $315-323$.

\section{How to cite this article:}

Pahari, A., A. Pradhan, S. Maity and Mishra, B.B. 2017. Carrier Based Formulation of Plant Growth Promoting Bacillus species and Their Effect on Different Crop Plants. Int.J.Curr.Microbiol.App.Sci. 6(5): 379-385. doi: http://dx.doi.org/10.20546/ijcmas.2017.605.043 